International Journal of Instruction e-ISSN: 1308-1470 • www.e-iji.net

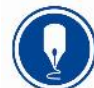

January $2022 \bullet$ Vol.15, No.1

p-ISSN: 1694-609X

pp. $717-732$

Article submission code

20210129082029

Received: 29/01/202

Revision: 01/08/202

Accepted: $24 / 08 / 202$

OnlineFirst: 14/11/2021

\title{
Assessing Transversal Competences in Professional Internships: The Role of Assessment Agents
}

Marina Romeo

Dr., Universitat de Barcelona, Spain, mromeo@ub.edu

Montserrat Yepes-Baldó

Dr., Universitat de Barcelona, Spain, myepes@ub.edu

Vicenta González

Dr., Universitat de Barcelona, Spain, vicentagonzalez@ub.edu

\section{Silvia Burset}

Dr., Universitat de Barcelona, Spain, sburset@ub.edu

\section{Carolina Martín}

Dr., Universitat de Barcelona, Spain, carolinamartin@ub.edu

\section{Emma Bosch}

Dr., Universitat de Barcelona, Spain, emmabosch@ub.edu

The assessment process in higher education considers four aspects: assessment agents, procedure, content, and scoring. In this study, we delve into the who. We analyze the role of transversal competence assessment agents in the framework of professional internships in university master's degree programs, comparing the suitability of their assessment based on their degree of experience in each master's program. Four university master's degree programs, in the field of human and social sciences, were analyzed. To ensure the degree of expert competence among the participating judges, the $\mathrm{K}$ coefficient was used. Two expert and two nonexpert judges independently assessed the critical incidents narrated by the students and inquired about the competences described in the curricula. The reliability index between the assessments from expert and nonexpert judges was analyzed. The results show greater reliability among the assessments of expert judges compared to nonexperts. As a result, we conclude the importance of basing the selection of assessors on objective expert competence and not on criteria more linked to academic management. It is also necessary to include the critical incident method as a systematic information collection system to explicitly assess transversal competences.

Keywords: assessment agents, transversal competences, master, professional internship, rubric

Citation: Romeo, M., Yepes-Baldó M., González, V., Burset, S., Martín, C., \& Bosh, E. (2022). Assessing transversal competences in professional internships: The role of assessment agents. International Journal of Instruction, 15(1), 717-732. https://doi.org/10.29333/iji.2022.15141a 


\section{INTRODUCTION}

Professional internships represent a challenge that various official university degrees have had to face. Implementing them involves a commitment to the employability of future graduates, enriching student training in this learning (Duda et al., 2019), in an environment that will provide both them and those responsible for training, a deeper knowledge of the skills they need in the future (RD 1393/2007).

For the Catalan University Quality Assurance Agency (AQU, 2009), the external body in charge of assessing Catalan universities and the accreditation processes of official degrees, the internship process involves mutual training and enrichment (between the university and society, company, institutions), since it facilitates the connection between the theory explained in the departments and daily experience in aspects of apparent social interest. Students bring the latest innovations that are being explored at the university and the internship centres collaborate in their training and they tend to strongly consider the assessment agents of this training (2009, p. 41).

This type of training requires systematic and rigorous assessment, for it to be continuously improved (della Volpe, 2017; Stufflebeam \& Shinkfield, 1987), hence various master's and postgraduate degrees have found it appropriate to be done by evaluation commissions comprising experts selected for their knowledge of the work conducted by students or practical experience in that area (Sanchís et al., 2017; Weinstein, 1993).

The main question that arises is if the rubrics can facilitate valid judgment of competence assessments. Even though different authors have pointed out the usefulness of rubrics (Suryanti \& Nurhuda, 2021), several authors (Jonsson \& Gvingby, 2007; Panadero \& Jonsson, 2020) stated the drawbacks of rubrics and concluded that rubrics do not facilitate valid judgment of performance assessments per se. In this sense, our research questions are 'Can the existence of assessment tools, such as rubrics, help to obtain more reliable evaluations? Are there any differences between experts and nonexperts on the assessment of competences using rubrics?'

\section{Background}

\section{Definitions of Transversal Competences}

There exist several studies trying to define and classify transversal competencies. Care et al. (2019) pointed out that go by many names but what they all have in common is an understanding that, while important, academic performance is only as good or as meaningful as the complementary skills and competencies that learners develop (2019, p. 1).

In this sense, Gibb (2014) called them soft or transferrable skills and stated that they represent a set of competencies referring to complex constructs and multiple related skills. Gallivan et al. (2004) classified transversal competences into communication skills, interpersonal skills, leadership skills, organizational skills, self-motivation skills and creativity skills. 
Transversal competences are defined as those that allow optimal training for professional practice, 'but also for the promotion of critical thinking and the culture of freedom and pluralism, as well as the transmission of civic and social values typical of a democratic society' (art. 3.2b of the Statute of the Universitat de Barcelona) (Decree 246/2003). In this sense, this kind of competences are not exclusive from a knowledge area but generalizable to all higher education studies.

In the context of our research, the Universitat de Barcelona, it was defined a set of transversal competencies to be developed during the master's degrees. For the present research, and once analysed the set of competencies developed in the curricula of the different masters included in the study, the following competencies were selected: originality and creativity, transference (capacity to applying knowledge in practice), ethical responsibility, communication, autonomy, and teamwork.

Following the Tuning Project classification of competencies (2007), the competencies analysed can be classified as instrumental (communication), interpersonal (ethical responsibility and teamwork), and systemic (originality and creativity, transference, autonomy).

There is no agreement on the best way to assess this kind of competencies. Some authors have indicated that it is fundamental to implement individualised mentoring processes (Garvey et al., 2008) or even to develop large-scale programmes for the deployment and assessment of transversal competencies (Weedon \& Tett, 2013). In the present research we propose the professional internships to put in practice the competencies developed by the students during their studies.

\section{The Assessment Processes}

The assessment process should consider the assessment procedure, content assessed, scoring, and the person assessing (Barroso Osuna \& Cabero Almenara, 2013). There are several studies analysing assessment procedures, contents, and scoring, but little is said about the person assessing. Thus, in this study, we take a closer look into who assesses the content, focusing on those who assess university master's degree internships.

Related to assessment procedures and scoring, and since the implementation of the European Higher Education Area (EHEA), rubrics have become a powerful instrument to assess any type of academic task, given the need to develop new ways to assess not only content but also competences that students are expected to develop (de la Cruz \& Abreu, 2012; Suryanti \& Nurhuda, 2021). The strength of this assessment tool is that it facilitates student involvement in the assessment process by promoting their selfregulation and autonomy.

Moreover, because students have the assessment criteria before starting their task, they are better able to structure its development, level of involvement necessary, as well as develop their critical capacity and the communication processes between the agents involved in the assessment (Cano, 2015).

In relation to the content assessed when considering transversal competencies, the critical incidents technique (Flanagan, 1954) has been used to measure the acquisition of 
students' competences, since it provides a basis to assess people's performance through behavioral, affective, and cognitive indicators, as well as to know the perception of students during their learning (Gathright et al., 2016; Kubberød \& Pettersen, 2018; Rawles, 2016; Tella et al., 2016).

Finally, regarding the person assessing, several authors discuss the difficulty of choosing experts, considering the many criteria that can be used in the selection process (Powell, 2003; Williams \& Webb, 1994). As a result, in the present research, to assure the degree of experts' competences, we used the so-called 'competence coefficients' or 'competence k' (Barroso Osuna \& Cabero Almenara, 2013). This coefficient is obtained based on the expert's opinion of their level of knowledge about the research topic, as well as from sources that allow them to argue the established criterion (Barroso Osuna \& Cabero Almenara, 2013, 29).

\section{Purpose}

The general objective of this study is to explore the role of transversal competence assessment agents in the framework of professional internships in university master's degrees, comparing the suitability of their assessment based on their degree of experience in each master's degree program.

\section{METHOD}

\section{Participants}

The sample was selected by convenience. It is composed of nine professors from different master's degree programs, who acted as experts in their knowledge field, and were in charge of assessing the critical incidents narrated by students in the master's degree programs under study $(\mathrm{n}=38$, participation rate $=52.1 \%)$. An accidental sampling was used for the student's sample.

To ensure the participating judges' degree of expert competence quantitatively and objectively, they all answered a questionnaire to calculate their expert competence coefficient or $\mathrm{K}$ coefficient (García \& Fernández, 2008; López, 2008). This questionnaire is based on the one developed by Barroso Osuna and Cabero Almenara (2013). To obtain the K coefficient, the formula proposed by the authors was used.

$$
\mathrm{K}=1 / 2(\mathrm{Kc}+\mathrm{Ka})
$$

Where:

Kc (knowledge coefficient): Judge's estimation, on a scale of $0-10$ and multiplied by 0.1 , of their information or knowledge in relation to the knowledge fields were analyzed.

Ka (reasoning coefficient): Judge's estimation, on a scale of low, medium, or high on the influence over a series of sources of reasoning. These refer to the justification attributed by the expert to the degree of knowledge indicated above.

A coefficient is assigned to each assessment, according to that indicated by the authors (García \& Fernández, 2008; López, 2008). The authors understand the subjects who obtain $\mathrm{K}$ scores higher than 0.8 to be experts. 


\section{Ethical Considerations}

To carry out this research, we followed the University of Barcelona's Code of Conduct for Research Integrity (Universitat de Barcelona, 2020). All participants received information about the objective of this research, and their anonymity was preserved.

\section{Instruments}

Based on the competence definitions established in the curricula, the research followed the procedure described by Flanagan (1954) to develop critical incidents. In the first phase, a critical incident questionnaire was administered to the students, where their professional experiences and internships prior to the master's degree program were analyzed. This questionnaire included aspects related to the transversal competences that coincide with the curricula of the four master's programs involved: arts interdisciplinary education (EIA, for its Spanish acronym), Spanish as a foreign language (ELE, Spanish acronym), management and development of people and teams in organizations (GDO, Spanish acronym), and psychology of organizations, work, and human resources (WOPP) (Table 1).

Table 1

Competences described in curricula and their correspondence with the critical incident interview script

\begin{tabular}{|c|c|}
\hline Curricula competences & Interview script \\
\hline $\begin{array}{l}\text { CB6. That students possess and understand } \\
\text { knowledge that provides a basis or opportunity to } \\
\text { be original in the development and/or application } \\
\text { of ideas, often in a research context. }\end{array}$ & $\begin{array}{l}\text { Can you explain a situation wherein your knowledge } \\
\text { allowed you to develop your task or training activity } \\
\text { in an original way? When did it occur? What } \\
\text { happened? }\end{array}$ \\
\hline $\begin{array}{l}\text { CB7. That students know how to apply the } \\
\text { acquired knowledge and their ability to solve } \\
\text { problems in new or unfamiliar environments } \\
\text { within broader (or multidisciplinary) contexts } \\
\text { related to their area of study. }\end{array}$ & $\begin{array}{l}\text { Can you explain a situation in which the knowledge } \\
\text { you acquired in a certain area allowed you to solve } \\
\text { problems in another area in which you were not } \\
\text { knowledgeable or one that was new to you? What } \\
\text { knowledge facilitated the positive resolution? }\end{array}$ \\
\hline $\begin{array}{l}\text { CB8. That students can integrate knowledge and } \\
\text { manage the complexity of making judgments based } \\
\text { on information that, while incomplete or limited, } \\
\text { includes reflections on the social and ethical } \\
\text { responsibilities tied to applying their knowledge } \\
\text { and judgments. }\end{array}$ & $\begin{array}{l}\text { Can you explain a situation when you made an } \\
\text { ethical and socially responsible judgment, even } \\
\text { though you had little information? When did it occur? } \\
\text { What happened? }\end{array}$ \\
\hline $\begin{array}{l}\text { CB9. That students know how to communicate } \\
\text { their conclusions and the knowledge and final } \\
\text { reasons that support them to specialized and non- } \\
\text { specialized audiences in a clear and unambiguous } \\
\text { way. }\end{array}$ & $\begin{array}{l}\text { Can you explain a situation when you had to } \\
\text { communicate and substantiate, to a specialized } \\
\text { audience (or not), some aspect of your work or } \\
\text { training activity? When did it occur? What } \\
\text { happened? What was the result? }\end{array}$ \\
\hline $\begin{array}{l}\text { CB10. That students possess the learning skills that } \\
\text { enable them to continue studying in a way that will } \\
\text { be largely self-guided or independent. }\end{array}$ & $\begin{array}{l}\text { Which three aspects do you consider key to } \\
\text { successfully developing in your professional career? }\end{array}$ \\
\hline $\begin{array}{l}\text { CG1. That students work as a team in accordance } \\
\text { with the social values of cooperation and attention } \\
\text { to diversity. }\end{array}$ & $\begin{array}{l}\text { Can you explain a situation when teamwork was } \\
\text { successful and another in which it was not? What } \\
\text { elements should have changed for it to be a success? }\end{array}$ \\
\hline
\end{tabular}

To assess the critical incidents, the judges used a simplified rubric (see Procedure) in which each competence was assessed using between one and four indicators. The 
deployment level scores for each indicator could range from 1 to 3 , with 3 being the maximum deployment level. If a judge did not observe indications in the critical incident that would allow them to assess the degree of deployment, they would indicate this with a 0 .

\section{Procedure. Development and Piloting of the Research Instrument}

Based on the critical incidents narrated, expert and nonexpert judges in each master's degree field had to score the degree of competence deployed, based on the simplified rubric (Appendix I). The critical incident assessment rubric was readjusted in two phases, namely, rubric fit and design and assessment. In the first phase, the judges indicated the fit of the rubric when assessing the level of deployment of the competences. For this purpose, pairs of expert judges independently analyzed the responses of each student and subsequently the nine judges jointly conducted a focus group to share their ratings.

The completion of this first phase resulted in the deployment levels being simplified, given the difficulties expressed by the judges when it came to clarify the differences between levels. Once the rubric was adjusted (Table 2), the judges worked in pairs to assess each narration independently. First, two judges who were expert in the master's program knowledge field assessed the students' critical incidents. Then, two judges who were nonexpert in the field of study reassessed the same critical incidents independently. 
Table 2

Final rubric with theoretical source of the indicators

\begin{tabular}{|c|c|c|}
\hline & $\begin{array}{l}\text { Theoretical } \\
\text { background }\end{array}$ & Indicators \\
\hline 正 & $\begin{array}{l}\text { Alsina et al. } \\
(2013)\end{array}$ & $\begin{array}{l}\text { CB6.1. View of reality that surrounds you and assessment of positive } \\
\text { and negative aspects of the suggested context } \\
\text { CB6.2. Integration of knowledge from different subjects to generate } \\
\text { ideas } \\
\text { CB6.3. Initiating and proposing innovative actions to face challenges }\end{array}$ \\
\hline 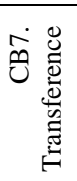 & $\begin{array}{l}\text { Alsina et al. } \\
(2013)\end{array}$ & $\begin{array}{l}\text { CB7.1. Previous proposal or design of an adequate process or procedure } \\
\text { to achieve the proposed objectives applicable to real situations } \\
\text { CB7.2. Applying theoretical knowledge to situations that arise in real or } \\
\text { simulated scenarios }\end{array}$ \\
\hline 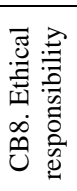 & $\begin{array}{l}\text { Alsina et al. } \\
(2013) \\
\text { GID-CAV }\end{array}$ & $\begin{array}{l}\text { CB8.1. Adequate management of situations that are significant, } \\
\text { complex, or conflictive from an ethical perspective } \\
\text { CB8.2. Practical implications of professional ethics in their activity }\end{array}$ \\
\hline 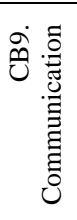 & $\begin{array}{l}\text { Dunbar, } \\
\text { Brooks, and } \\
\text { Kubicka-Miller } \\
\text { (2006) } \\
\text { Alsina et al. } \\
(2013)\end{array}$ & $\begin{array}{l}\text { CB9.1. Communication with a specific objective } \\
\text { CB9.2. Use of appropriate supporting material (use of examples, } \\
\text { statistics, citations, and other resources that support the information } \\
\text { shared) } \\
\text { CB9.3. Appropriate use of language } \\
\text { CB9.4. Reasoning of the presentation }\end{array}$ \\
\hline$\stackrel{\substack{\grave{0} \\
0}}{\stackrel{0}{0}}$ & GID-CAV & $\begin{array}{l}\text { CB10. Independent lifelong learning as a prerequisite for professional } \\
\text { development }\end{array}$ \\
\hline ن己 & $\begin{array}{l}\text { Alsina et al. } \\
(2013)\end{array}$ & $\begin{array}{l}\text { CG1.1. Sharing knowledge and information with the team } \\
\text { CG1.2. Involvement in group goals and constructive feedback } \\
\text { CG1.3. Assessing the importance of teamwork }\end{array}$ \\
\hline
\end{tabular}

\section{FINDINGS}

The main results obtained are shown below. First, the participating judges were classified according to their expert competence coefficient based on the area under study in the four master's degree programs analyzed. Specifically, the areas correspond to human resources (HR), for the master's degrees in Management and Development of People and Teams in Organizations (GDO) and Work, Organizational and Personnel Psychology (WOP-P); interdisciplinary education of the arts for the master's degree in Interdisciplinary Arts Education (EIA); and Spanish as a foreign language for the master's degree in Spanish as a Foreign Language (ELE). As can be seen in Table 4, at least two of the judges obtained scores in the expert competence coefficient above 0.8 , 
which, according to Barroso Osuna and Cabero Almenara (2013), is the minimum value to ensure its adequacy. The judges who did not obtain this score were classified as nonexperts for that knowledge field.

To balance the number of expert judges in each field, the two with the highest scores in the $\mathrm{K}$ coefficient were selected. For EIA, because four judges had the same score, the two experts with the most years of experience in this field were selected. Since the HR area had the most contributions from students, nonexpert judges were divided into three pairs.

All the judges, both experts and nonexperts, assessed the critical incidents reported by the students using the simplified rubric presented in the Instruments section. No significant differences were observed, calculated using t-Student for independent samples, in relation to the means given by expert judges compared to nonexperts.

The indicators that obtained the highest average scores were 'CB7.2. Applying theoretical knowledge to situations that arise in real or simulated scenarios' from the 'Transference' competence, both among expert and nonexpert judges, 'CG1.3. Assessment of teamwork collaboration' for experts, and 'CG1.2. Involvement in the group's objectives and constructive feedback' for nonexperts, both belonging to the 'Teamwork' competence.

In contrast, the indicators that obtained the worst assessments were 'CB9.4. Reasoning of the presentation', in both judge groups, and 'CB9.2. Use of adequate supporting material (examples, statistics, citations, and other resources that support the information shared),' among the expert judges. Both indicators are part of the 'Communication' competence. This competence obtained the highest number of 0 ratings, indicating that the set of judges found that the incidents described could not be used to assess the existence and degree of deployment of the indicators for this competence.

To analyze the degree of reliability between the judges' independent assessments, the Krippendorff alpha index was used for ordinal variables (Krippendorff, 2004). A good degree of reliability is between 1 and 0.8 . Conversely, below 0.667 would indicate an unacceptable degree of agreement. Table 3 shows the reliability analysis in the assessments for each indicator based on the type of assessing judge. Moreover, a third column shows the alpha calculated from the ratings given by all the judges together.

In general, the results indicate that the fit between judges improves when they are experts in the area of study they are assessing. Additionally, the fit levels between expert and nonexpert judges taken together are the lowest obtained, not reaching the established minimum of 0.667 in any case.

Two competences did not meet the minimum requirement to be considered adequate, although the reliability of expert judges was better than that obtained by nonexperts. These included the Autonomy and Teamwork competences. Furthermore, in the 'CG1.3. Assessment of teamwork collaboration' indicator from this last competence, the alpha of the nonexpert judges is slightly higher than that of the experts. 
Table 3

Degree of agreement between judges measured using Krippendorf's alpha

\begin{tabular}{|c|c|c|c|c|}
\hline Compe-tence & INDICATOR & EXPERTS & $\begin{array}{l}\text { NON- } \\
\text { EXPERTS }\end{array}$ & COMBINED \\
\hline \multirow{3}{*}{ 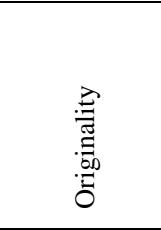 } & $\begin{array}{l}\text { CB6.1. View of reality that surrounds you and } \\
\text { assessment of positive and negative aspects of } \\
\text { the suggested context }\end{array}$ & .711 & .685 & .86 \\
\hline & $\begin{array}{l}\text { CB6.2. Integration of knowledge from different } \\
\text { subjects to generate ideas }\end{array}$ & .86 & .177 & .173 \\
\hline & $\begin{array}{l}\text { CB6.3. Initiating and proposing innovative } \\
\text { actions to face challenges }\end{array}$ & .672 & .549 & .176 \\
\hline \multirow{2}{*}{ 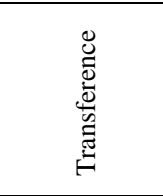 } & $\begin{array}{l}\text { CB7.1. Previous proposal or design of an } \\
\text { adequate process or procedure to achieve the } \\
\text { proposed objectives applicable to real situations }\end{array}$ & .754 & .42 & .424 \\
\hline & $\begin{array}{l}\text { CB7.2. Applying theoretical knowledge to } \\
\text { situations that arise in real or simulated } \\
\text { scenarios }\end{array}$ & .783 & .235 & .254 \\
\hline \multirow{2}{*}{ 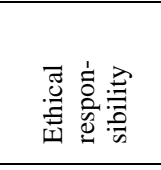 } & $\begin{array}{l}\text { CB8.1. Adequate management of situations that } \\
\text { are significant, complex, or conflictive from an } \\
\text { ethical perspective }\end{array}$ & .694 & .67 & .424 \\
\hline & $\begin{array}{l}\text { CB8.2. Practical implications of professional } \\
\text { ethics in their activity }\end{array}$ & .78 & .75 & .38 \\
\hline \multirow{4}{*}{ 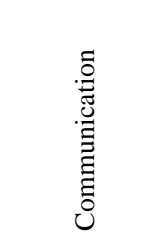 } & CB9.1. Communication with a specific objective & .822 & .542 & .169 \\
\hline & $\begin{array}{l}\text { CB9.2. Use of adequate supporting material (use } \\
\text { of examples, statistics, citations, and other } \\
\text { resources that support the information shared) }\end{array}$ & .814 & .382 & .196 \\
\hline & CB9.3. Appropriate use of language & .693 & .23 & .362 \\
\hline & CB9.4. Reasoning of the presentation & .772 & .334 & .383 \\
\hline$\stackrel{1}{\stackrel{\Xi}{ٍ}}$ & $\begin{array}{l}\text { CB10. Independent lifelong learning as a } \\
\text { prerequisite for professional development }\end{array}$ & .663 & .531 & .274 \\
\hline \multirow{3}{*}{ 詞 } & $\begin{array}{l}\text { CG1.1. Sharing knowledge and information with } \\
\text { the team }\end{array}$ & .446 & .388 & .223 \\
\hline & $\begin{array}{l}\text { CG1.2. Involvement in group goals and } \\
\text { constructive feedback }\end{array}$ & .617 & .133 & .375 \\
\hline & CG1.3. Assessing the importance of teamwork & .54 & .644 & .421 \\
\hline
\end{tabular}

\section{DISCUSSION}

The main objective of our study was to conduct an exploratory analysis on the adequacy of assessment agents for transversal competences in the framework of professional internships in university master's degree programs. When specifically analyzing the results obtained by each competence, we found that the reliability achieved by the expert judges when analyzing the integration of knowledge from different subjects to generate ideas was especially significant, an indicator within the Originality competence. This competence and the specified indicator have added value in the internships, as one of the objectives of internships is to be able to incorporate the knowledge acquired during training in the master's program to generate new ideas in their field of work and 
acquiring readiness for labor inclusion (Kpareliotis \& Patsiotis, 2019). The means that the expert judges assigned to this indicator showed medium-low levels of development.

Moreover, two communication competence indicators, adapting to the target and using supporting materials also obtained adequate reliability levels among expert judges. However, in both cases, the mean assessments provided by the judges indicate mediumlow or low levels of development. These results indicate the need to pay special attention to the development of these competences during master's degree studies as they are considered key aspects to facilitate employability (Chhinzer \& Russo, 2018).

Regarding the transference competence, it has been considered one of the most challenging as it is difficult to define, to differentiate from other competences and to assess (Gibb, 2014; Guilland, 2017). In the present research, although the degree of reliability does not reach the optimal level, the assessment's mean given by both expert and nonexpert judges indicates medium-high levels of development, which indicates that this is one of the competences that has been most developed in professional work and in internships (generally undergraduate) prior to entering the master's program. This is a good indicator of the ability to transfer the knowledge acquired in a theoretical context, considering the quality of teaching in university programs.

Finally, independent lifelong learning as a prerequisite for professional development and teamwork obtain low levels of reliability among the competences valued by the expert and nonexpert judges, as well as the most developed with medium and medium-high scores. For the rubric used to measure Autonomy, to minimize responses that incur the bias of social desirability, the students were asked about the three aspects that they felt were key to successfully developing their professional career. This made it easier for the different judges to infer different levels of deployment in cases where the competence was not explicit. Thus, for example, given the statement 'Knowing where I want to go and what I need to do it,' one of the expert judges awarded a score of 1, since it inferred that the student does not believe that independent lifelong learning and continuous education are key elements for their professional development, while the other judge gave a score of 2, indicating that the student expressed it implicitly.

As for teamwork, traditionally, it has been considered a core competence for success in a labor context. Nevertheless, according to the last reports of the World Economic Forum $(2016,2020)$, its importance has been progressively decreasing from position 2 in 2015 to 3 in 2016 and disappearing from the list of the top 15 skills for 2025 in the last report (World Economic Forum, 2020).

In our research, none of the three indicators reached adequate levels of reliability, although their assessment on the level of development is one of the highest, both for expert and nonexpert judges. The critical incident analysis narrated and assessed in a different way by expert judges shows how an incident can include evidence of different competences, which is differently valued by the judges. An example is found in the following verbatim:

In my previous job, we always worked as a team. I was in various customer service positions. When all of us who worked that shift were paying attention to what was 
communicated on the walkie by other people, the process happened without a problem. In that case, communication was essential for the team to be effective.

And vice versa, there was not good teamwork on the days when communication with coworkers was not adequate. Sometimes, miscommunication was caused by poor work management or high stress that led the person to speak badly to the co-worker. The change in this case would focus on empathetic and assertive communication (GDO master).

In this case, one of the judges thought that the student values the importance of teamwork, awarding a score of 3, while the other thought that there is no evidence of development of this indicator, awarding a zero, stating that this quote focuses on the importance of communication rather than teamwork.

\section{Limitations and Suggestions for Further Research}

While all curricula of the analyzed masters include the transversal competences to be developed in the internship period, in general, the assessment of professional internships does not include an explicit assessment of these competences. In this sense, one of the main contributions of our work is suggesting the inclusion of the critical incident method as a systematic information collection system to assess them.

Furthermore, we have empirically demonstrated the importance of determining who should be responsible for this assessment, in addition to what and how. In this sense, the factor of having experts, who perceive themselves as such and who have sources of theoretical reasoning and well-founded experience, improves the reliability of their assessments. While all the master's programs analyzed have a dual assessment of the professional internships, conducted by the internship center mentor and the faculty counsellor, we find it absolutely necessary to ensure that choosing assessors truly conforms to the criteria of objective expert competence.

Finally, the present research has analyzed four masters in the social sciences area. Future research should extend the analysis to other masters and other knowledge areas. Additionally, we used the experts' score as a method to assess the level of competence deployment. As a future research we will include the self-assessment of students on their critical incidents to analyze the correspondence between the scorings of experts and learners.

\section{CONCLUSION}

The quality of any training result is closely related to the quality of all the processes involved. In this sense, we must ensure maximum effectiveness in the assessment processes of students, key pieces in the higher education system, which transfers to society the transformative knowledge that has always characterized universities. Our results highlighted the importance of basing the selection of assessors on objective expert competence and not on criteria more linked to academic management. It is also necessary to include the critical incident method as a systematic information collection system to explicitly assess transversal competences. 


\section{REFERENCES}

Alsina, J., Argila, A., Aróztegui, M., Arroyo, F.J., Badia, M., Carreras, A., Colomer, M., et al. (2013). Rúbricas para la evaluación de competencias. [Rubrics for competency assessment.]. Octaedro.

AQU. (2009). Guia per a l'avaluació de competències en el Pràcticum de mestrela. Agencia para la Calidad del Sistema Universitario de Catalunya. http://www.aqu.cat/doc/doc_29617381_1.pdf

Barroso Osuna, J. M. \& Cabero Almenara, J. (2013). La utilización del juicio de experto para la evaluación de TIC: el coeficiente de competencia experta. Bordón. Revista de Pedagogía, 65(2),

25-38. https://recyt.fecyt.es/index.php/BORDON/article/view/brp.2013.65202

Cano, E. (2015). Las rúbricas como instrumento de evaluación de competencias en educación superior: ¿uso o abuso? Profesorado: Revista de Currículum y Formación del Profesorado, 19(2), 1-16. https://www.ugr.es/ recfpro/rev192COL2.pdf

Care, E., Vista, A., \& Kim, H. (2019). Assessment of transversal competencies: Current tools in the Asian region. United Nations Educational, Scientific and Cultural Organization. https://unesdoc.unesco.org/ark:/48223/pf0000368479

Chhinzer, N., \& Russo, A. M. (2018). An exploration of employer perceptions of graduate student employability. Education and Training, 60(1), 104-120. doi: https://doi.org/10.1108/ET-06-2016-0111

de la Cruz, G. \& Abreu, L. F. (2012). Atributos de tutores de posgrado por campo disciplinario: La perspectiva de estudiantes de la Universidad Nacional Autónoma de México. Perfiles Educativos, 34(138), 10-27.

della Volpe, M. (2017). Assessment of internship effectiveness in South Italy Universities. Education + Training, 59(7/8), 797-810. https://doi.org/10.1108/ET-082016-0136

Decree 246/2003. (2003, October 8). Aproving the Statute of Universitat de Barcelona. https://www.ub.edu/web/ub/galeries/documents/universitat/estatut_ub_dogc3993_200310-22.pdf

Duda, H. J., Susilo, H., \& Newcombe, P. (2019). Enhancing different ethnicity science process skills: problem-based learning through practicum and authentic assessment. International Journal of Instruction, 12(1), 1207-1222. https://doi.org/10.29333/iji.2019.12177a

Dunbar, N. E., Brooks, C. F., \& Kubicka-Miller, T. (2006). Oral communication skills in higher education: Using a performance-based evaluation rubric to assess communication skills. Innovative Higher Education, 31(2), 115-128. https://doi.org/10.1007/s10755-006-9012-x 
Flanagan, J. C. (1954). The critical incident technique. Psychological Bulletin, 51(4), 327-358.

Gallivan, M., Truex, D., \& Kvasny, L. (2004). Changing patterns in IT skill sets 19882003. The DATABASE for Advances in Information Systems, 35(3), 64-87. https://doi.org/10.1145/1017114.1017121

García, L. \& Fernández, S. (2008). Procedimiento de aplicación del trabajo creativo en grupo de expertos. Ingeniería Energética, 12(2), 46-50. https://www.redalyc.org/articulo.oa?id=329127758006

Garvey, B., Stokes, P., \& Megginson, D. (2008). Coaching and mentoring: Theory and practice. Sage.

Gathright, M. M., Thrush, C., Guise, J. B., Krain, L., \& Clardy, J. (2016). What do medical students perceive as meaningful in the psychiatry clerkship learning environment? A content analysis of critical incident narratives. Academic Psychiatry, 40(2), 287-294. https://doi.org/10.1007/s40596-015-0303-3

Guilland, A. (2017). SOCCES handbook - Assessment of transversal competences: Focus on entrepreneurship, sense of initiative and social skills. Laurea University of Applied Sciences. https://www.theseus.fi/bitstream/handle/10024/123611/Laurea\%20julkaisut\%2077.pdf? sequence $=1$ \&isAllowed $=\mathrm{y}$

Jonsson, A., \& Svingby, G. (2007). The use of scoring rubrics: Reliability, validity, and educational consequences. Educational Research Review, 2(2), 130-144. https://doi.org/10.1016/j.edurev.2007.05.002

Kapareliotis, I., Voutsina, K., \& Patsiotis, A. (2019). Internship and employability prospects: assessing student's work readiness. Higher Education, Skills and Work-Based Learning, 9(4), 538-549. https://doi.org/10.1108/HESWBL-08-2018-0086

Krippendorff, K. (2004). Content analysis: An introduction to its methodology (2nd ed.). Sage.

Kubberød, E., \& Pettersen, I.B. (2018). The role of peripherality in students' entrepreneurial learning. Education + Training, 60(1), 2-15. https://doi.org/10.1108/ET-06-2016-0106

López, A. (2008). La moderación de la habilidad diagnóstico patológico desde el enfoque histórico cultural para la asignatura Patología Veterinaria. Revista Pedagógica Universitaria, 13(5), 51-71.

Panadero, E., \& Jonsson, A. (2020). A critical review of the arguments against the use of rubrics. Educational Research Review, 30, 100329. https://doi.org/10.1016/j.edurev.2020.100329

Powell, C. (2003). The Delphi technique: myths and realities. Journal of Advanced Nursing, 41(4), 376-382. https://doi.org/10.1046/j.1365-2648.2003.02537.x. 
Rawles, J. (2016). Developing social work professional judgment skills: Enhancing learning in practice by researching learning in practice. Journal of Teaching in Social Work, 36(1), 102-122. https://doi.org/10.1080/08841233.2016.1124004

Royal Decree 1393/2007 (2007, October 29) by which the organization of official university education is established. BOE.

Sanchis, P., Lopez-Martin, A., Pérez-Artieda, G., Gubía, E., Astrain, D., LopezTaberna, J., ... \& Matías, I. R. (2017, April). New organizational and assessment frameworks for company internship programs. In 2017 IEEE Global Engineering Education Conference (EDUCON) (pp. 877-882). IEEE.

Stufflebeam, D. L., \& Shinkfield, A. J. (1987). Evaluación sistemática: guía teórica y práctica [Systematic assessment: theory and practice]. Paidós.

Suryanti, N., \& Nurhuda (2021). The effect of problem-based learning with an analytical rubric on the development of students' critical thinking skills. International Journal of Instruction, 14(2). https://doi.org/10.29333/iji.2021.14237a

Tella, S., Smith, N. J., Partanen, P., \& Turunen, H. (2016). Work placements as learning environments for patient safety: Finnish and British preregistration nursing students' important learning events. Journal of Vocational Education and Training, 68(1), 51-69. https://doi.org/10.1080/13636820.2015.1104715

Tuning Project. (2007). Tuning educational structures in Europe. http://www.unideusto.org/tuningeu/images/stories/documents/General_Brochure_final_v ersion.pdf

Universitat de Barcelona. (2020). The University of Barcelona's code of conduct for research integrity. Edicions de la Universitat de Barcelona. http://diposit.ub.edu/dspace/bitstream/2445/166917/3/Codi_integritat_en_la_recerca.pdf

Weedon, E., \& Tett, L. (2013). Plugging a gap? Soft skills courses and learning for work. International Journal of Lifelong Education, 32(6), 724-740. https://doi.org/10.1080/02601370.2013.773572

Weinstein, B. D. (1993). What is an expert? Theoretical Medicine, 14, 57-73. https://doi.org/10.1007/BF00993988

Williams, P. L., \& Webb, C. (1994). The Delphi technique: a methodological discussion. Journal of Advanced Nursing, 19(1), 180-186. https://doi.org/10.1111/j.1365-2648.1994.tb01066.x

World Economic Forum. (2016). The future of jobs. Employment, skills, and workforce strategy for the fourth industrial revolution. Global Challenge Insight Report. http://www3.weforum.org/docs/WEF_Future_of_Jobs.pdf

World Economic Forum. (2020). The future of jobs report 2020. http://www3.weforum.org/docs/WEF_Future_of_Jobs_2020.pdf 
Romeo, Yepes-Baldó, González, Burset, Martín \& Bosh

Appendix I

Initial rubric

\begin{tabular}{|c|c|c|c|c|c|}
\hline & & 1 & 2 & 3 & 4 \\
\hline \multirow[b]{3}{*}{ 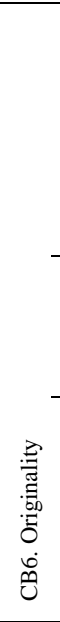 } & $\begin{array}{l}\text { CB6.1. View of reality } \\
\text { that surrounds you and } \\
\text { assessment of positive } \\
\text { and negative aspects of } \\
\text { the suggested context }\end{array}$ & $\begin{array}{l}\text { There is no } \\
\text { indication that } \\
\text { any aspect of } \\
\text { the current } \\
\text { situation is } \\
\text { questioned }\end{array}$ & $\begin{array}{l}\text { Analyzes the } \\
\text { current situation } \\
\text { or problem in } \\
\text { relation to one's } \\
\text { immediate } \\
\text { environment }\end{array}$ & $\begin{array}{l}\text { Knows how to } \\
\text { analyze the } \\
\text { context } \\
\text { surrounding a } \\
\text { situation in the } \\
\text { short and } \\
\text { medium term } \\
\text { and prevent its } \\
\text { evolution }\end{array}$ & $\begin{array}{l}\text { Analyzes the } \\
\text { context of a } \\
\text { situation } \\
\text { identifying } \\
\text { aspects that can } \\
\text { be improved }\end{array}$ \\
\hline & $\begin{array}{l}\text { CB6.2. Integration of } \\
\text { knowledge from } \\
\text { different subjects to } \\
\text { generate ideas }\end{array}$ & $\begin{array}{l}\text { Does not } \\
\text { integrate any } \\
\text { prior knowledge } \\
\text { in proposals }\end{array}$ & $\begin{array}{l}\text { Integrates } \\
\text { different prior } \\
\text { knowledge, but } \\
\text { does not provide } \\
\text { original ideas } \\
\end{array}$ & $\begin{array}{l}\text { Integrates } \\
\text { knowledge to } \\
\text { offer original } \\
\text { ideas }\end{array}$ & $\begin{array}{l}\text { Integrates } \\
\text { knowledge to } \\
\text { contribute ideas } \\
\text { that improve a } \\
\text { problem }\end{array}$ \\
\hline & $\begin{array}{l}\text { CB6.3. Initiating and } \\
\text { proposing innovative } \\
\text { actions to face } \\
\text { challenges }\end{array}$ & $\begin{array}{l}\text { Does not } \\
\text { express } \\
\text { reflections on } \\
\text { potential ways } \\
\text { to develop a } \\
\text { task }\end{array}$ & $\begin{array}{l}\text { Recognizes the } \\
\text { potential } \\
\text { existence of } \\
\text { alternative } \\
\text { processes, but } \\
\text { does not apply } \\
\text { them to the } \\
\text { current situation } \\
\end{array}$ & $\begin{array}{l}\text { Proactively } \\
\text { seeks new } \\
\text { methods to } \\
\text { perform certain } \\
\text { tasks }\end{array}$ & $\begin{array}{l}\text { Searches for } \\
\text { innovative } \\
\text { procedures and } \\
\text { applies them } \\
\text { while } \\
\text { performing tasks } \\
\text { and assessing } \\
\text { the results } \\
\end{array}$ \\
\hline \multirow{2}{*}{ 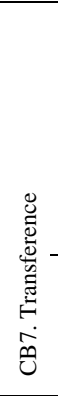 } & $\begin{array}{l}\text { CB7.1. Previous } \\
\text { proposal or design of } \\
\text { an adequate process or } \\
\text { procedure to achieve } \\
\text { the proposed objectives } \\
\text { applicable to real } \\
\text { situations }\end{array}$ & $\begin{array}{l}\text { Not able to } \\
\text { design the } \\
\text { required process } \\
\text { or procedure }\end{array}$ & $\begin{array}{l}\text { The process or } \\
\text { procedure } \\
\text { designed does } \\
\text { not adapt to the } \\
\text { desired results } \\
\text { due to lack of } \\
\text { important } \\
\text { elements or } \\
\text { indicators }\end{array}$ & $\begin{array}{l}\text { Designs a } \\
\text { process or } \\
\text { procedure that is } \\
\text { used to solve a } \\
\text { specific } \\
\text { situation, but } \\
\text { does not review } \\
\text { it for } \\
\text { improvement }\end{array}$ & $\begin{array}{l}\text { Designs an } \\
\text { efficient process } \\
\text { or procedure, } \\
\text { adapted to the } \\
\text { situation, and } \\
\text { conducts a } \\
\text { systematic } \\
\text { review }\end{array}$ \\
\hline & $\begin{array}{l}\text { CB7.2. Applying } \\
\text { theoretical knowledge } \\
\text { to situations that arise } \\
\text { in real or simulated } \\
\text { scenarios } \\
\end{array}$ & $\begin{array}{l}\text { The knowledge } \\
\text { acquired is not } \\
\text { applied and the } \\
\text { problems faced } \\
\text { are not solved } \\
\end{array}$ & $\begin{array}{l}\text { The knowledge } \\
\text { acquired is not } \\
\text { applied, but the } \\
\text { problems faced } \\
\text { are solved }\end{array}$ & $\begin{array}{l}\text { Acquired } \\
\text { knowledge is } \\
\text { applied, but the } \\
\text { problems faced } \\
\text { are not solved } \\
\end{array}$ & $\begin{array}{l}\text { Acquired } \\
\text { knowledge is } \\
\text { applied and the } \\
\text { problems faced } \\
\text { are solved }\end{array}$ \\
\hline \multirow{2}{*}{ 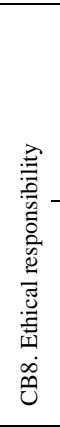 } & $\begin{array}{l}\text { CB8.1. Adequate } \\
\text { management of } \\
\text { situations that are } \\
\text { significant, complex, or } \\
\text { conflictive from an } \\
\text { ethical perspective }\end{array}$ & \multicolumn{3}{|l|}{$\begin{array}{l}\text { Avoids or does not get } \\
\text { involved when required } \\
\text { to solve a specific } \\
\text { activity that simulates } \\
\text { ethically significant } \\
\text { situations }\end{array}$} & $\begin{array}{l}\text { Shows reflective, } \\
\text { critical, and proactive } \\
\text { behavior in performing } \\
\text { the action that is } \\
\text { significant, complex, or } \\
\text { conflictive from a moral } \\
\text { perspective }\end{array}$ \\
\hline & $\begin{array}{l}\text { CB8.2. Practical } \\
\text { implications of } \\
\text { professional ethics in } \\
\text { their activity }\end{array}$ & $\begin{array}{l}\text { There is no evidence } \\
\text { that they consider the } \\
\text { practical implications of } \\
\text { professional ethics in } \\
\text { their activity }\end{array}$ & \multicolumn{2}{|c|}{$\begin{array}{l}\text { Expresses disagreement } \\
\text { in situations that do not } \\
\text { respect the ethical and } \\
\text { deontological principles } \\
\text { of the profession in } \\
\text { situations that are not } \\
\text { consistent with them }\end{array}$} & $\begin{array}{l}\text { Defends and commits to } \\
\text { act consistently with } \\
\text { ethical and } \\
\text { deontological concepts, } \\
\text { paying attention to all } \\
\text { its complexity and } \\
\text { integrating a critical and } \\
\text { responsible perspective }\end{array}$ \\
\hline نै & $\begin{array}{l}\text { CB9.1. } \\
\text { Communication with } \\
\text { a specific objective }\end{array}$ & $\begin{array}{l}\text { Pays little or no } \\
\text { attention to } \\
\text { context, } \\
\text { audience, and } \\
\text { purpose }\end{array}$ & $\begin{array}{l}\text { Demonstrates } \\
\text { knowledge of } \\
\text { context, } \\
\text { audience, and } \\
\text { purpose }\end{array}$ & $\begin{array}{l}\text { Demonstrates } \\
\text { appropriate } \\
\text { consideration of } \\
\text { context, } \\
\text { audience, and } \\
\text { purpose }\end{array}$ & $\begin{array}{l}\text { Demonstrates a } \\
\text { deep } \\
\text { understanding of } \\
\text { context, } \\
\text { audience, and } \\
\text { purpose }\end{array}$ \\
\hline
\end{tabular}

International Journal of Instruction, January $2022 \bullet$ Vol.15, No.1 


\begin{tabular}{|c|c|c|c|c|c|}
\hline & $\begin{array}{l}\text { CB9.2. Use of } \\
\text { adequate supporting } \\
\text { materials (examples, } \\
\text { statistics, citations, } \\
\text { and other resources } \\
\text { that support the } \\
\text { information shared) }\end{array}$ & $\begin{array}{l}\text { The supporting } \\
\text { materials } \\
\text { (explanations, } \\
\text { examples, } \\
\text { citations) that } \\
\text { support the } \\
\text { information and } \\
\text { analysis are } \\
\text { insufficient and } \\
\text { do not } \\
\text { demonstrate } \\
\text { mastery of the } \\
\text { subject in } \\
\text { question }\end{array}$ & $\begin{array}{l}\text { The supporting } \\
\text { materials } \\
\text { (explanations, } \\
\text { examples, } \\
\text { citations) that } \\
\text { support the } \\
\text { information and } \\
\text { analysis are } \\
\text { partially } \\
\text { compatible with } \\
\text { the presentation } \\
\text { and partially } \\
\text { demonstrate } \\
\text { mastery of the } \\
\text { subject in } \\
\text { question }\end{array}$ & $\begin{array}{l}\text { The supporting } \\
\text { materials } \\
\text { (explanations, } \\
\text { examples, } \\
\text { citations) that } \\
\text { support the } \\
\text { information and } \\
\text { analysis are } \\
\text { generally } \\
\text { compatible with } \\
\text { the presentation } \\
\text { and establish } \\
\text { mastery and } \\
\text { authority of the } \\
\text { subject in } \\
\text { question }\end{array}$ & $\begin{array}{l}\text { Uses a wide } \\
\text { variety of } \\
\text { supporting } \\
\text { materials } \\
\text { (explanations, } \\
\text { examples, } \\
\text { citations) that } \\
\text { significantly } \\
\text { support the } \\
\text { information and } \\
\text { analysis of the } \\
\text { presentation and } \\
\text { establish mastery } \\
\text { and authority on } \\
\text { the subject in } \\
\text { question }\end{array}$ \\
\hline & $\begin{array}{l}\text { CB9.3. Appropriate } \\
\text { use of language }\end{array}$ & $\begin{array}{l}\text { The language is } \\
\text { unclear and } \\
\text { minimally } \\
\text { supports effective } \\
\text { communication }\end{array}$ & $\begin{array}{l}\text { The language is } \\
\text { clear and partially } \\
\text { supports effective } \\
\text { communication }\end{array}$ & $\begin{array}{l}\text { The language is } \\
\text { solid, clear, and } \\
\text { generally } \\
\text { supports effective } \\
\text { communication }\end{array}$ & $\begin{array}{l}\text { The language is } \\
\text { compelling and } \\
\text { imaginative and } \\
\text { fully supports } \\
\text { effective } \\
\text { communication }\end{array}$ \\
\hline & $\begin{array}{l}\text { CB9.4. Reasoning of } \\
\text { the presentation }\end{array}$ & $\begin{array}{l}\text { Demonstrates an } \\
\text { attempt to use } \\
\text { ideas to support } \\
\text { their argument }\end{array}$ & $\begin{array}{l}\text { Demonstrates an } \\
\text { attempt to use } \\
\text { credible or } \\
\text { relevant sources } \\
\text { to support ideas } \\
\text { specific to the } \\
\text { subject }\end{array}$ & $\begin{array}{l}\text { Demonstrates } \\
\text { constant use of } \\
\text { credible or } \\
\text { relevant sources } \\
\text { to support ideas } \\
\text { specific to the } \\
\text { subject }\end{array}$ & $\begin{array}{l}\text { Demonstrates } \\
\text { skillful, high- } \\
\text { quality use of } \\
\text { credible or } \\
\text { relevant ideas } \\
\text { and sources that } \\
\text { are fully } \\
\text { appropriate for } \\
\text { the subject }\end{array}$ \\
\hline 它 & $\begin{array}{l}\text { CB10. Independent } \\
\text { lifelong learning as a } \\
\text { prerequisite for } \\
\text { professional } \\
\text { development }\end{array}$ & $\begin{array}{l}\text { Does not consider } \\
\text { independent lifelong } \\
\text { learning and continuing } \\
\text { education to be key } \\
\text { elements for } \\
\text { professional } \\
\text { development } \\
\end{array}$ & \multicolumn{2}{|c|}{$\begin{array}{ll}\text { Implicitly considers } \\
\text { independent lifelong } \\
\text { learning and continuing } \\
\text { education to be key } \\
\text { elements for } \\
\text { professional } \\
\text { development } \\
\end{array}$} & $\begin{array}{l}\text { Explicitly considers } \\
\text { independent lifelong } \\
\text { learning and continuing } \\
\text { education to be key } \\
\text { elements for } \\
\text { professional } \\
\text { development }\end{array}$ \\
\hline \multirow[b]{3}{*}{ 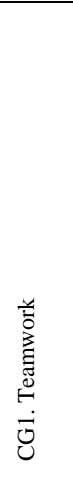 } & $\begin{array}{l}\text { CG1.1. Sharing } \\
\text { knowledge and } \\
\text { information } \\
\text { with the team }\end{array}$ & $\begin{array}{l}\text { Pursues specific } \\
\text { goals }\end{array}$ & $\begin{array}{l}\text { ersonal goals } \\
\text { ake priority over } \\
\text { hose of the } \\
\text { roup }\end{array}$ & $\begin{array}{l}\text { Pursues the } \\
\text { group's } \\
\text { objectives }\end{array}$ & $\begin{array}{l}\text { Promotes and } \\
\text { deploys the } \\
\text { group's } \\
\text { objectives }\end{array}$ \\
\hline & $\begin{array}{l}\text { CG1.2. } \\
\text { Involvement in } \\
\text { group goals and } \\
\text { constructive } \\
\text { feedback }\end{array}$ & $\begin{array}{l}\text { Does not get } \\
\text { involved and is a } \\
\text { hindrance }\end{array}$ & $\begin{array}{l}\text { s not involved } \\
\text { ut is not a } \\
\text { indrance }\end{array}$ & $\begin{array}{l}\text { Accepts the } \\
\text { opinions of others } \\
\text { and offers their } \\
\text { viewpoints in a } \\
\text { constructive way }\end{array}$ & $\begin{array}{l}\text { Encourages } \\
\text { constructive } \\
\text { dialog. Integrates } \\
\text { and inspires } \\
\text { participation from } \\
\text { others }\end{array}$ \\
\hline & $\begin{array}{l}\text { CG1.3. } \\
\text { Assessment of } \\
\text { teamwork } \\
\text { collaboration }\end{array}$ & $\begin{array}{l}\text { Rejects the } \\
\text { importance of } \\
\text { teamwork }\end{array}$ & $\begin{array}{l}\text { Minimizes the } \\
\text { mportance of } \\
\text { eamwork. } \\
\text { ersonal goals } \\
\text { ake priority over } \\
\text { hose of the } \\
\text { roup }\end{array}$ & $\begin{array}{l}\text { Supports } \\
\text { teamwork }\end{array}$ & $\begin{array}{l}\text { Values the } \\
\text { importance of } \\
\text { teamwork }\end{array}$ \\
\hline
\end{tabular}

International Journal of Instruction, January $2022 \bullet$ Vol.15, No.1 